\title{
STUDI ABU PUING UBIN KERAMIK SEBAGAI BAHAN PENGGANTI SEBAGIAN SEMEN TERHADAP MUTU BATA BETON UNTUK PASANGAN DINDING
}

\author{
Hadi Sutanto, Gina Bachtiar, SW Astuti
}

\begin{abstract}
Abstrak
This research aims to find out the differences of concrete brick quality for wall set which used ruins dust of ceramic floor tile as substitute material with percentage level $15 \%, 20 \%$, and $25 \%$ of cement weight concerning the quality of concrete brick IV for wall set based on Indonesia National Standard (SNI 03-0349-1989).

This research is carried out at Balai Bahan \& Barang Teknik Dinas Perindustrian DKI Jakarta Laboratory at JI. Let. Jen Suprapto Cempaka Putih, Jakarta.

This research used experimental method. The number of sample was 60 of 4 treatments, each group of treatment was 15, with details 10 for pressurable testing and 5 for water absorption testing.

The result shows that concrete brick without ruins dust of ceramic floor tile have pressurable 40, $12 \mathrm{~kg} / \mathrm{cm} 2$ in average with water absorption 12,62\% in average, concrete brick with $15 \%$ ruins dust of ceramic floor tile have pressurable $30,07 \mathrm{~kg} / \mathrm{cm} 2$ in average with water absorption 13, 76\% in average, concrete brick with $20 \%$ ruins dust of ceramic floor tile have pressurable $28,23 \mathrm{~kg} / \mathrm{cm} 2$ in average with water absorb capability 13, 91\% whereas for concrete brick with $25 \%$ ruins dust of ceramic floor tile have pressurable $27,02 \mathrm{~kg} / \mathrm{cm} 2$ in average with water absorb capability $14,46 \%$ in average.

Data analysis technique which was used ANAVA test, from pressurable data was gained Fcount=20, 81 and Ftable=4,38. As the result Fcount $>$ Ftable, so Ho was rejected. Whereas from water absorption data was gained Fcount=14, 23 and Ftable $=4$, 38. As the result Fcount>Ftable and Ho was rejected. The result shows the existence of differences of concrete brick quality for wall set with $0 \%$, $15 \%, 20 \%$, and $25 \%$ ruins dust of ceramic floor tile.
\end{abstract}

Keywords : concrete brick

\section{PENDAHULUAN}

Sejalan dengan meningkatnya pembangunan di segala sektor yang kian menjamur layaknya di musim penghujan maka semakin berkurangnya keberadaannya dan semakin bertambah mahalnya material yang digunakan untuk pembangunan gedung, jalan raya ataupun bendungan. Di Indonesia dalam hal kelangkaan sesuatu bahan sering menyebabkan meningkatnya harga jual bahan tersebut. Oleh karena itu perlu dicari sebuah solusi untuk menghindari hal tersebut.

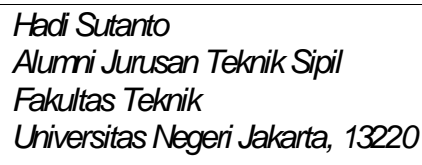

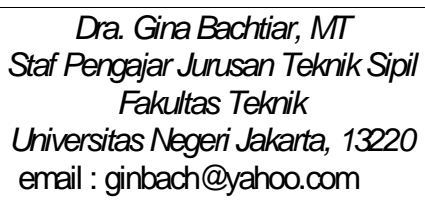

Dra. SW Astuti, M.Pd

Staf Pengajar Jurusan Teknik Sipil

Fakultas Teknik

Universitas Negeri Jakarta, 13220 
Pada pembangunan rumah-rumah sederhana bata beton untuk pasangan dinding yang biasa disebut dengan batako masih sangat sering digunakan. Karena harganya cukup murah dan penggunaannya lebih hemat. Di Indonesia penggunaan bata beton ini sudah tidak terlalu asing lagi, terutama penggunaan pada pembuatan rumah-rumah sederhana. Pabrik-pabrik pembuatan bata beton saat ini pun tidak terlalu sulit untuk ditemukan.

Bata beton untuk pasangan dinding adalah salah satu bahan bangunan dengan berbagai macam bentuk yang terbuat dari semen, agregat dan air serta bahan aditif lainnya dengan campuran tertentu tanpa mengurangi mutunya. Bata beton sering digunakan karena proses pelaksanaan pemasangannya yang tidak terlalu sulit.

Bahan pengikat hidrolis yang digunakan untuk pembuatan bata beton adalah semen portland. Semen portland sebagai bahan pengikat dalam pembuatan bata beton merupakan bahan bangunan yang juga sangat sering digunakan untuk pembangunan gedung ataupun jalan raya. Oleh karena itu untuk mencegah langkanya bahan bangunan tersebut maka perlu dicari alternatif bahan penggantinya terutama semen, karena harga semen setiap waktunya akan terus melonjak naik.

Di pabrik-pabrik banyak terdapat limbah yang menumpuk dan tak dapat digunakan lagi. Begitu juga dengan pabrik proses pengolahan industri keramik lantai, ada dua macam limbah yang tidak dapat dimanfaatkan kembali, diantaranya : (1) limbah cair, berupa sisa pengglasuran permukaan keramik, (2) limbah padat, berupa puing-puing ubin keramik yang gagal atau cacat produksi.

Limbah padat industri keramik merupakan ubin keramik cacat produksi disebabkan pecah di dalam tungku, cacat glasur dan cacat penampakan (bentuk dan warna). Limbah padat industri keramik ini lambat laun akan menumpuk, tapi untuk hal tersebut ada baiknya apabila limbah padat industri keramik tersebut dapat digunakan kembali.

Menurut hasil penelitian yang dilakukan di laboratorium Kimia FMIPA UI limbah padat keramik yang telah dihaluskan menjadi abu puing ubin keramik mengandung silika. Silika merupakan salah satu senyawa kimia yang paling penting dalam semen setelah kapur. Kadar silika yang terkandung di dalam abu puing ubin keramik ini sebesar 58,39\%. Oleh karena itu diduga bahwa abu puing ubin keramik akan dapat berfungsi sebagai bahan pengikat hidrolis yang dapat menggantikan sebagian dari semen portland untuk pembuatan bata beton untuk pasangan dinding sehingga dapat meningkatkan nilai ekonomi pembuatan bata beton untuk pasangan dinding.

Berdasarkan pembahasan tersebut di atas, maka ditarik beberapa permasalahan yang dapat diteliti diantaranya adalah : Apakah ada perbedaan kuat tekan antara bata beton biasa dengan bata beton yang dibuat dengan abu puing ubin keramik sebagai bahan pengganti sebagian semen? Berapa perbandingan yang baik untuk abu puing ubin keramik sebagai bahan pengganti sebagian semen pada pembuatan bata beton? Apakah abu puing ubin keramik dapat menggantikan sebagian semen pada 
pembuatan bata beton? Apakah bata beton yang terbuat dengan bahan pengganti abu puing ubin keramik mempunyai daya serap air yang lebih baik? Apakah mutu bata beton yang terbuat dengan bahan pengganti abu puing ubin keramik dapat memenuhi persyaratan mutu Standar Nasional Indonesia 03-0349-1989 mutu IV?

Dari identifikasi beberapa masalah tersebut maka batasan permasalahan yang akan diteliti adalah mengenai Mutu Bata Beton menggunakan abu puing ubin keramik sebagai bahan pengganti sebagian semen dengan persentase 15\%, 20\% dan 25\% dari berat semen. Berdasarkan pada pembatasan masalah di atas maka dapat dirumuskan permasalahan sebagai berikut : Apakah mutu bata beton yang menggunakan abu puing ubin keramik sebagai bahan pengganti sebagian semen dengan persentase 15\%, 20\% dan 25\% dari berat semen memenuhi persyaratan Standar Nasional Indonesia 03-0349-1989 mutu IV?

\section{METODA}

Tujuan penelitian ini adalah untuk mengetahui :

a. Apakah nilai kuat tekan bata beton dengan abu puing keramik sebagai bahan pengganti sebagian semen dengan persentase $15 \%, 20 \%$ dan $25 \%$ dari berat semen masing-masing dapat memenuhi mutu IV bata beton untuk pasangan dinding Standar Nasional Indonesia 03-0349-1989?

b. Apakah nilai penyerapan air bata beton dengan abu puin ubin keramik sebagai bahan pengganti sebagian semen dengan persentase 15\%, 20\% dan 25\% dari berat masing-masing semen dapat memenuhi mutu IV bata beton untuk pasangan dinding Standar Nasional Indonesia 03-0349-1989?

Penelitian dan pembuatan bata beton dilaksanakan di laboratorium Balai Penelitian Bahan Dinas Perindustrian DKI, Jl. Letjen. Suprapto Cempaka Putih, Jakarta Pusat. Puing ubin keramik didapat dari Trimulia Keramik, Jl. Inspeksi Kalimalang No. 1B, Jakarta Timur. Penggilingan/penghalusan puing keramik lantai di laboratorium fisika Puspitek Serpong. Penelitian untuk mengetahui kandungan kimia abu puing ubin keramik di laboratorium kimia Universitas Indonesia, Depok.

Metoda penelitian yang digunakan dalam penelitian ini adalah metode eksperimen di laboratorium dengan benda uji bata beton untuk pasangan dinding yang menggunakan abu puing ubin keramik sebagai bahan pengganti sebagian semen portland.

Variabel - variabel penelitian ini yaitu :

1. Variabel bebas yaitu penggunaan abu puing ubin keramik sebagai bahan pengganti sebagian semen.

2. Varibel terikat yaitu mutu bata beton. 
Prosedur penelitian di laboratorium adalah berdasarkan cara uji kuat tekan bata beton menurut SNI 030349-1989.

Prosedur kerja penelitian ini meliputi :

\section{Tahap Pemeriksaan Bahan}

Pemeriksaan bahan dilakukan terhadap masing-masing bahan dasar agar diketahui sifat-sifat bahan tersebut seperti di bawah ini :

a. Semen

Untuk semen tidak dilakukan pengujian karena sudah memenuhi syarat semen portland. Pada penelitian ini digunakan semen tipe I cap Tiga Roda.

b. Agregat Halus (pasir)

(1) Pemeriksaan zat organik dalam pasir

Tujuannya untuk menentukan adanya kandungan bahan organik dalam pasir, dimana dapat memenuhi kualitas bata beton. Prosedur pengujian ini sesuai dengan SNI 03-28161990.

(2) Pengujian indeks kekerasan butiran pasir

Pengujian indeks kekerasan pasir sesuai dengan SNI 03-1756-1990.

(3) Pengujian kadar lumpur

Pengujian kadar lumpur pasir sesuai dengan SNI 03-1754-1990.

(4) Pengujian gradasi pasir

Prosedur penelitian ini sesuai dengan SNI 03-1968-1990.

(5) Pengujian analisis specifik grafity dan penyerapan air pasir

Pengujian ini dilakukan sesuai dengan SNI 03-1970-1990.

C. Air

Air yang digunakan dalam penelitian ini adalah air PAM, maka tidak dilakukan pemeriksaan karena telah memenuhi standar persyaratan.

\section{Tahap Pembuatan Benda Uji}

Pada penelitian ini dibuat benda uji dengan ukuran $41 \mathrm{~cm} \times 21 \mathrm{~cm} \times 10 \mathrm{~cm}$ dengan menggunakan alat cetak bata beton untuk pasangan dinding. Perbandingan berat untuk campuran semen dan pasir pada pembuatan bata beton ini digunakan campuran $1 \mathrm{sp}: 6 \mathrm{ps}$. Abu puing ubin keramik digunakan sebagai bahan pengganti sebagian semen pada variasi yang berbeda yaitu 15\%, 20\% dan $25 \%$. 


\section{Tahap Pengujian Benda Uji}

Pengujian kuat tekan dan penyerapan air bata beton pada penelitian ini disesuaikan dengan SNI 03 - 0349 - 1989. Pengujian siap dilakukan setelah bata beton berumur 28 hari, sedangkan pemeriksaan yang dilakukan sebelum pengujian adalah memeriksa ukuran dan berat bata beton. Hasil pengujian kuat tekan bata beton sebanyak 40 buah berupa nilai kuat tekan rata-rata $(\mathrm{kg} / \mathrm{cm})$. Penyerapan air diuji setelah bata beton direndam selama 24 jam yang sebelumnya telah diketahui berat kering oven bata beton tersebut. Hasil pengujian penyerapan air bata beton sebanyak 20 buah berupa nilai persentasi kadar air rata-rata (\%).

\section{Rancangan Penelitian}

Adapun perlakuan yang akan diberikan untuk kelompok bata beton adalah :

1. Kelompok $A_{0}$, ( $0 \%$ abu puing ubin keramik $+100 \%$ semen) : 6 pasir

2. Kelompok $A_{1}$, ( $15 \%$ abu puing ubin keramik $+85 \%$ semen) : 6 pasir

3. Kelompok $A_{2}$, (20\% abu puing ubin keramik $+80 \%$ semen) : 6 pasir

4. Kelompok $A_{3}$, (25\% abu puing ubin keramik $+75 \%$ semen) : 6 pasir

\section{Teknik Pengambilan Populasi dan Sampel}

\section{Populasi}

Populasi dalam penelitian ini adalah bata beton dengan abu puing ubin keramik sebagai bahan pengganti sebagian semen dengan persentase $15 \%, 20 \%$ dan $25 \%$ dari berat semen.

\section{Sampel}

Sampel yang digunakan pada penelitian ini adalah bata beton dengan abu puing ubin keramik sebagai bahan pengganti sebagian semen dari 4 perlakuan dengan jumlah benda uji dari masing-masing perlakuan sebanyak 10 buah yang jumlah keseluruhannya sebanyak 40 benda uji. Menurut SNI 03 0349 - 1989 pengambilan sampel dilakukan secara acak sebanyak 10 buah benda uji untuk pengujian kuat tekan dan 5 buah benda uji pula untuk pengujian penyerapan air.

\section{Teknik Pengambilan Data}

1. Pengumpulan data

Pengumpulan data dilakukan dengan menguji kuat tekan bata beton dengan mesin uji kuat tekan bata beton. 
2. Instrumen

Instrumen yang digunakan untuk penelitian adalah alat pencetak bata beton, alat penggiling/penghalus batu, seperangkat alat ukur (panjang, berat, volume dan waktu), seperangkat alat uji untuk agregat halus, seperangkat alat uji untuk kuat tekan bata beton dan blanko pengisian data.

\section{Teknik Analisis Data}

Pada penelitian ini sebelum dilakukan pengujian hipotesis, terlebih dahulu data perlu diuji normalitas dan homogenitas. Persyaratan analisis data untuk menguji normalitas data menggunakan uji Liliefors, sedangkan persyaratan analisis data untuk menguji homogenitas data menggunakan uji Barlett. Untuk pengujian hipotesis digunakan pengujian analisis variansi.

\section{Hipotesis Statistik}

Hipotesis statistik dalam penelitian ini yaitu :

1. Hipotesis pertama : $H_{0}: \propto_{A}=\propto_{S}$, artinya : mutu bata beton untuk pasangan dinding yang menggunakan abu puing ubin keramik dengan mutu IV bata beton untuk pasangan dinding Standar Nasional Indonesia adalah sama.

2. Hipotesis kedua : $H_{1}: \propto_{A}>\propto_{S}$, artinya : mutu bata beton untuk pasangan dinding yang menggunakan abu puing ubin keramik mempunyai nilai yang lebih baik daripada mutu IV bata beton untuk pasangan dinding Standar Nasional Indonesia.

\section{HASIL DAN PEMBAHASAN}

Hasil Pengujian Ukuran Bata Beton

Data-data hasil pengujian ukuran bata beton untuk tiap perlakuan dapat dilihat pada tabel 1 berikut ini :

Tabel 1 Hasil Pengujian Ukuran Bata Beton

\begin{tabular}{|c|c|c|c|c|c|c|}
\hline \multirow{2}{*}{ Kelompok } & \multicolumn{7}{|c|}{ Ukuran Rata-rata Bata Beton } \\
\cline { 2 - 7 } & $\begin{array}{c}\text { Panjang } \\
\text { (mm) }\end{array}$ & $\begin{array}{c}\text { Lebar } \\
(\mathbf{m m})\end{array}$ & $\begin{array}{c}\text { Tebal } \\
(\mathbf{m m})\end{array}$ & $\begin{array}{c}\text { Berat } \\
(\mathbf{k g})\end{array}$ & Tebal dinding (mm) \\
\hline $\mathrm{A}_{0}$ & 409,5 & 208,6 & 103,6 & 12,693 & 25,5 & 27,0 \\
\hline $\mathrm{A}_{1}$ & 408,9 & 207,7 & 103,1 & 12,440 & 25,1 & 26,7 \\
\hline $\mathrm{A}_{2}$ & 409,1 & 208,1 & 102,8 & 12,318 & 24,5 & 26,0 \\
\hline $\mathrm{A}_{3}$ & 408,9 & 208,1 & 102,1 & 12,219 & 24,7 & 27,1 \\
\hline
\end{tabular}




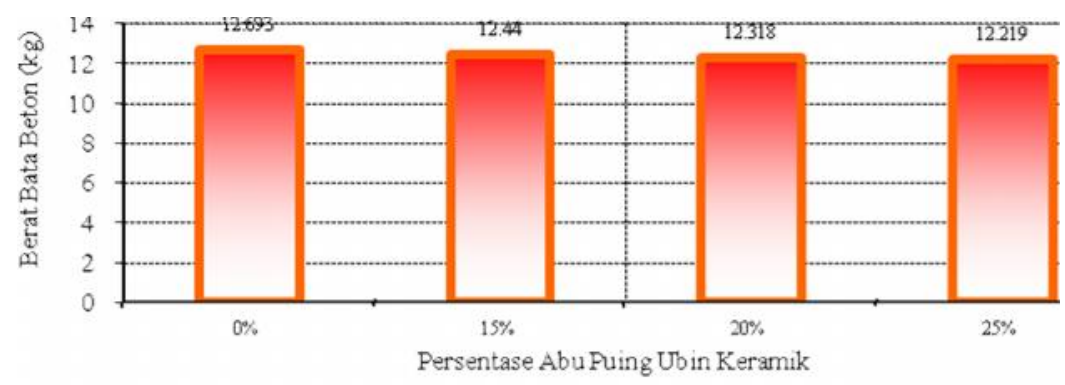

Gambar 1. Grafik Berat Bata Beton

Dari tabel tersebut dapat terlihat bahwa penggunaan bahan pengganti abu puing ubin keramik untuk sebagian semen pada pembuatan bata beton untuk pasangan dinding menghasilkan bata beton yang lebih ringan. Hal ini menunjukkan adanya pengaruh penggunaan abu puing ubin keramik sebagai bahan pengganti sebagian semen terhadap berat bata beton yang dihasilkan.

\section{Hasil Pengujian Kuat Tekan Bata beton}

Data hasil pengujian berupa kuat tekan bata beton yang ditunjukkan oleh jarum penunjuk pada mesin uji tekan. Data-data hasil pengujian kuat tekan bata beton untuk tiap perlakuan dapat dilihat pada tabel 2 berikut :

Tabel 2 Hasil Pengujian Kuat Tekan Bata beton

\begin{tabular}{|c|c|c|c|}
\hline \multirow{2}{*}{ Kelompok } & \multicolumn{3}{|c|}{ Nilai Kuat Tekan (Kg/cm $\left.{ }^{2}\right)$} \\
\cline { 2 - 4 } & Minimum & Maksimum & Rata-rata \\
\hline$A_{0}$ & 35,61 & 45,72 & 40,12 \\
$A_{1}$ & 24,21 & 34,74 & 30,07 \\
$A_{2}$ & 21,79 & 33,99 & 28,23 \\
$A_{3}$ & 22,73 & 31,44 & 27,02 \\
\hline
\end{tabular}

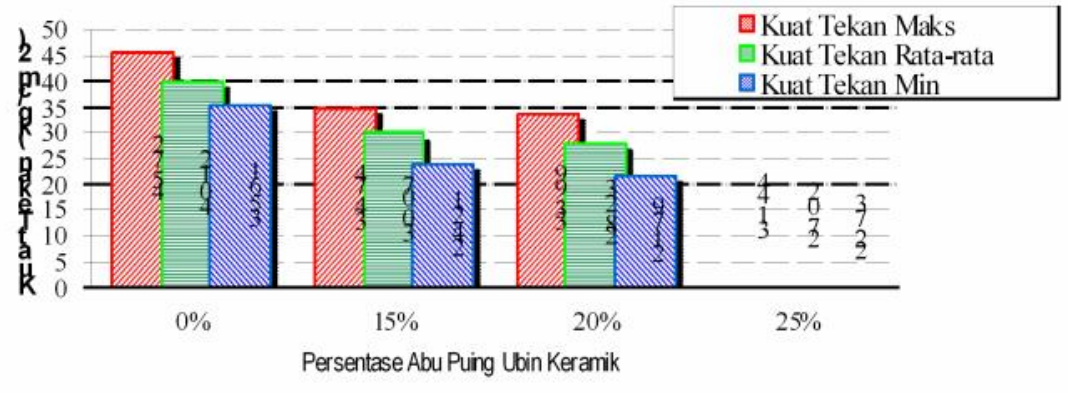

Gambar 2. Grafik Kuat Tekan Bata Beton 
Dari tabel dan gambar grafik tersebut dapat terlihat bahwa hasil pengujian bata beton pada tiap perlakuan menghasilkan nilai kuat tekan yang lebih besar dari bata beton mutu IV SNI 03-0349-1989 $\left(20 \mathrm{~kg} / \mathrm{cm}^{2}\right)$. Dapat terlihat juga adanya penurunan nilai kuat tekan bata beton dengan bertambahnya persentase abu puing ubin keramik.

\section{Hasil Pengujian Penyerapan Air Bata Beton}

Hasil pengujian penyerapan air pada bata beton diperoleh dari pengujian untuk tiap perlakuan dapat dilihat pada tabel 3 berikut.

\section{Tabel 3 Hasil Pengujian Penyerapan Air Bata beton}

\begin{tabular}{|c|c|c|c|}
\hline \multirow{2}{*}{ Kelompok } & \multicolumn{3}{|c|}{ Penyerapan Air (\%) } \\
\cline { 2 - 4 } & Minimum & Maksimum & Rata-rata \\
\hline$A_{0}$ & 12,36 & 12,81 & 12,62 \\
$A_{1}$ & 12,81 & 14,69 & 13,76 \\
$A_{2}$ & 13,30 & 14,38 & 13,91 \\
$A_{3}$ & 14,27 & 14,59 & 14,46 \\
\hline
\end{tabular}

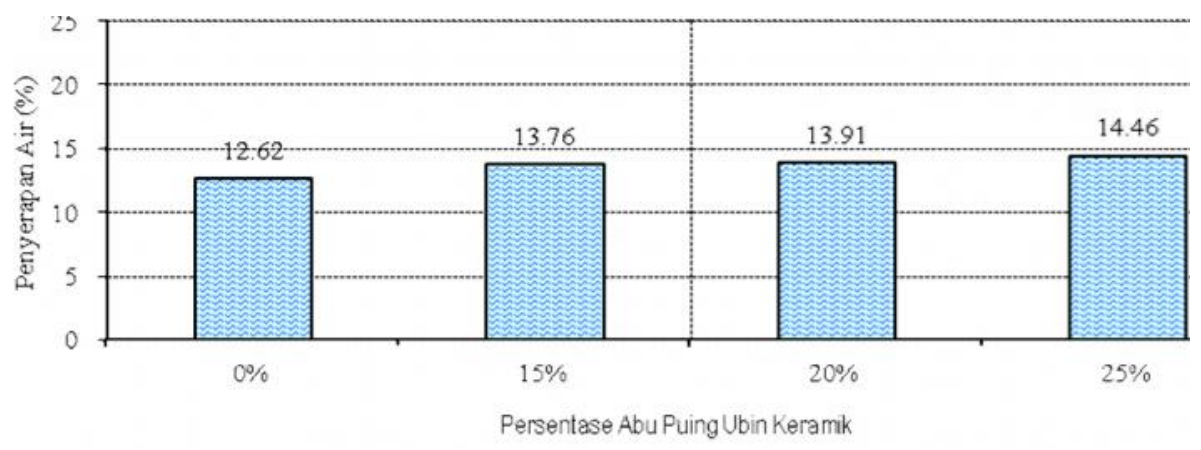

Gambar 3. Grafik Penyerapan Air Rata-rata

Berdasarkan tabel dan grafik tersebut dapat terlihat adanya peningkatan nilai penyerapan air pada setiap bertambahnya persentase abu puing ubin keramik. Semua nilai hasil pengujian penyerapan air tersebut dapat memenuhi bata beton untuk pasangan dinding mutu I SNI 03 - 0349 - 1989 (25\%).

\section{Pengujian Persyaratan Analisis Kuat Tekan}

Untuk memenuhi persyaratan dalam pengujian hipotesis, terlebih dahulu dilakukan pengujian normalitas dan homogenitas dari data kuat tekan bata beton. 


\section{Uji Normalitas Kuat Tekan Bata Beton}

Tabel 4 Uji Normalitas Penyerapan Air Bata Beton Tanpa Bahan Pengganti Abu Puing Ubin Keramik

\begin{tabular}{|l|c|c|c|}
\hline \multicolumn{1}{|c|}{ Subjek } & $\mathbf{L}_{\text {hitung }}\left(\mathrm{L}_{0}\right)$ & $\mathbf{L}_{\text {tabel }}\left(\mathbf{L}_{\mathbf{t}}\right)$ & Kesimpulan \\
\hline $\begin{array}{l}\text { Bata beton tanpa abu puing ubin } \\
\text { keramik }\end{array}$ & 0,1474 & 0,2940 & $\begin{array}{c}\mathrm{L}_{\text {hitung }}<\mathrm{L}_{\text {tabel }} \\
\text { (Distribusi normal) }\end{array}$ \\
\hline
\end{tabular}

Tabel 5 Uji Normalitas Penyerapan Air Bata Beton Dengan Persentase Bahan Pengganti Abu Puing Ubin Keramik 15\%

\begin{tabular}{|l|c|c|c|}
\hline \multicolumn{1}{|c|}{ Subjek } & $\mathbf{L}_{\text {hitung }}\left(\mathbf{L}_{0}\right)$ & $\mathbf{L}_{\text {tabel }}\left(\mathbf{L}_{t}\right)$ & Kesimpulan \\
\hline $\begin{array}{l}\text { Bata beton dengan persentase 15\% } \\
\text { abu puing ubin keramik }\end{array}$ & 0,2051 & 0,2940 & $\begin{array}{c}L_{\text {hitung }}<L_{\text {tabel }} \\
\text { (Distribusi normal) }\end{array}$ \\
\hline
\end{tabular}

Tabel 6 Uji Normalitas Penyerapan Air Bata Beton Dengan Persentase Bahan Pengganti Abu Puing Ubin Keramik 20\%

\begin{tabular}{|l|c|c|c|}
\hline \multicolumn{1}{|c|}{ Subjek } & $\mathrm{L}_{\text {hitung }}\left(\mathrm{L}_{0}\right)$ & $\mathrm{L}_{\text {tabel }}\left(\mathrm{L}_{\mathrm{t}}\right)$ & Kesimpulan \\
\hline $\begin{array}{l}\text { Bata beton dengan persentase 20\% } \\
\text { abu puing ubin keramik }\end{array}$ & 0,1714 & 0,2940 & $\begin{array}{c}\mathrm{L}_{\text {hitung }}<\mathrm{L}_{\text {tabel }} \\
\text { (Distribusi normal) }\end{array}$ \\
\hline
\end{tabular}

Tabel 7 Uji Normalitas Penyerapan Air Bata Beton Dengan Persentase Bahan Pengganti Abu Puing Ubin Keramik 25\%

\begin{tabular}{|l|c|c|c|}
\hline \multicolumn{1}{|c|}{ Subjek } & $\mathbf{L}_{\text {hitung }}\left(\mathbf{L}_{0}\right)$ & $\mathbf{L}_{\text {tabel }}\left(\mathbf{L}_{\mathrm{t}}\right)$ & Kesimpulan \\
\hline $\begin{array}{l}\text { Bata beton dengan persentase 25\% } \\
\text { abu puing ubin keramik }\end{array}$ & 0,1594 & 0,2940 & $\begin{array}{c}\text { Lhitung }<\mathrm{L}_{\text {tabel }} \\
\text { (Distribusi normal) }\end{array}$ \\
\hline
\end{tabular}

Uji Homogenitas Penyerapan Air Bata Beton

Tabel 8 Hasil Uji Homogenitas

\begin{tabular}{|c|c|c|}
\hline $\mathbf{X}^{2}$ hitung & $\mathbf{X}^{2}$ tabel & Hasil \\
\hline 10,86 & 11,3 & $\begin{array}{c}\mathbf{X}^{2} \text { hitung }<\mathbf{X}^{2} \text { tabel } \\
\text { (Data Homogen) }\end{array}$ \\
\hline
\end{tabular}

\section{Pengujian Hipotesis Penyerapan Air Bata Beton}

Rangkuman hasil Uji Analisis Varians dapat dilihat pada tabel 9 berikut ini :

Tabel 9 Hasil Uji Analisis Varians

\begin{tabular}{|l|c|c|c|c|c|}
\hline \multicolumn{1}{|c|}{ Daftar variansi } & Dk & JK & KT & $\mathbf{F}_{\text {hitung }}$ & $\mathbf{F}_{\text {tabel }}$ \\
\hline Rata-rata & 1 & 3747,5 & 3747,5 & & \\
Antar Kelompok & 3 & 8,972 & 2,99 & 14,23 & 4,38 \\
Dalam Kelompok & 16 & 3,358 & 0,21 & & \\
\hline \multicolumn{1}{|c|}{ Total } & $\mathbf{2 0}$ & & & & \\
\hline
\end{tabular}


Dari tabel tersebut di atas dengan dk pembilang 3, dk penyebut 16 dan peluang 0,99 (taraf nyata $\alpha=$ 0,01 ) didapat $F_{\text {tabel }}=4,38$ dan $F_{\text {hitung }}=14,23$. ternyata $F_{\text {hitung }}>F_{\text {tabel }}$ maka $\mathrm{H}_{0}$ ditolak dalam taraf signifikan $(\alpha)=0,01$. (hasil perhitungan dapat dilihat pada lampiran 30 hal. 110). Kesimpulannya adalah terdapat perbedaan antara nilai penyerapan air bata beton dengan menggunakan abu puing ubin keramik $0 \%, 15 \%, 20 \%$ dan $25 \%$.

\section{Intepretasi Hasil Penelitian}

Berdasarkan hasil penelitian ini terdapat hubungan antara hasil pengujian kuat tekan dengan hasil pengujian penyerapan air bata beton, dimana adanya pengaruh dari jumlah persentasi bahan pengganti sebagian semen yaitu abu puing ubin keramik terhadap hasil pengujian kuat tekan dan penyerapan air bata beton untuk pasangan dinding.

Semakin bertambahnya persentasi bahan pengganti sebagian semen yaitu abu puing ubin keramik, maka semakin menurunnya kuat tekan yang didapat dan semakin meningkatnya nilai persentasi penyerapan air pada bata beton untuk pasangan dinding. Pernyataan tersebut dapat memberikan penjelasan bahwa hasil pengujian kuat tekan pada bata beton semakin menurun, maka penyerapan air pada bata beton menjadi meningkat.

\section{Pembahasan}

Hasil pengujian benda uji bata beton yang menggunakan abu puing ubin keramik sebagai bahan pengganti sebagian semen sebesar 0\%, 15\%, 20\% dan 25\% memberikan nilai kuat tekan dan penyerapan air bata beton yang berbeda-beda, meskipun demikian nilai rata-rata hasil pengujian kuat tekan dan penyerapan air tersebut dapat memenuhi mutu IV pada SNI 03 - 0349 - 1989 (bata beton untuk pasangan dinding).

Perbedaan nilai kuat tekan dan nilai penyerapan air tersebut telah dibuktikan pada pengujian hipotesis secara statistik yang menyatakan bahwa nilai rata-rata kuat tekan dan nilai rata-rata penyerapan air yang dihasilkan dari bahan abu puing ubin keramik sebagai pengganti sebagian semen untuk bata beton untuk pasangan dinding secara signifikan menghasilkan mutu yang lebih baik daripada bata beton untuk pasangan dinding mutu IV SNI 03-0349-1989.

Berdasarkan hal tersebut di atas, maka kesimpulan yang dapat ditarik dari pembahasan hasil penelitian ini adalah penggunaan abu puing ubin keramik sebagai bahan pengganti sebagian semen sampai sebesar $25 \%$ dari berat semen pada pembuatan bata beton untuk pasangan dinding ternyata dapat digunakan. 


\section{Keterbatasan Penelitian}

Dalam penelitian ini, peneliti mengakui banyak keterbatasan penelitian yang disebabkan oleh beberapa hal, antara lain :

1. Peneliti tidak menguji mutu bata beton dengan persentase abu puing ubin keramik kurang dari $15 \%$ dan lebih dari $25 \%$ dari berat semen.

2. Peneliti hanya menguji mutu bata beton untuk pasangan dinding dengan perbandingan campuran 1 sp : 6 psr.

3. Peneliti hanya menguji mutu bahan abu puing ubin keramik sebagai pengganti sebagian semen tetapi tidak memperhitungkan dan membandingkan besar biaya pembuatan bata beton standar dan yang menggunakan bahan abu puing ubin keramik.

4. Kemungkinan terjadinya kesalahan pengukuran dalam pembacaan jarum uji kuat tekan pada waktu pengujian bata beton dan kemungkinan kurangnya ketelitian dalam perhitungan.

5. Keterbatasan sumber bacaan dan pengetahuan peneliti yang mempengaruhi proses pengujian dan analisa hasil pengujian.

\section{KESIMPULAN}

1. Nilai minimum kuat tekan bata beton yang menggunakan abu puing ubin keramik ternyata masih dapat melebihi nilai kuat tekan bata beton Standar Nasional Indonesia Mutu IV $\left(20 \mathrm{Kg} / \mathrm{cm}^{2}\right)$, sedangkan dengan nilai hasil pengujian penyerapan air untuk semua perlakuan pada bata beton dapat dikatakan termasuk pada mutu I karena kadar airnya masih di bawah 25\%.

2. Nilai kuat tekan rata-rata bata beton yang optimum dicapai oleh kelompok bata beton pada penggunaan abu puing ubin keramik $15 \%$ yaitu sebesar $30,07 \mathrm{Kg} / \mathrm{cm}^{2}$. Sedangkan bata beton pada penggunaan abu puing ubin keramik $20 \%$ sebesar $28,23 \mathrm{Kg} / \mathrm{cm}^{2}$ dan bata beton pada penggunaan abu puing ubin keramik $25 \%$ sebesar $27,02 \mathrm{Kg} / \mathrm{cm}^{2}$. Dimana dari ketiga perlakuan tersebut memenuhi persyaratan bata beton untuk pasangan dinding Standar Nasional Indonesia 03-0349-1989 dan ke dalam tingkat mutu IV yaitu minimal mempunyai kuat tekan rata-rata sebesar $20 \mathrm{Kg} / \mathrm{cm}^{2}$.

3. Semakin tinggi persentase abu puing ubin keramik yang diberikan maka penyerapan airnya semakin besar, beratnya semakin ringan dan kuat tekannya semakin menurun. 


\section{DAFTAR PUSTAKA}

Dept. Metallurgy \& Materials Enginering, 2004. Hasil Penelitian Abu Puing Ubin Keramik, Universitas Indonesia, Depok.

Dinas Perindustrian DKI Jakarta, Petunjuk Teknis Proses Pembuatan Bata Beton. Balai Penelitian Bahan. Jakarta

Isyani, lis, 1999. Studi Pemanfaatan Limbah Abu Bagase Sebagai Bahan Substitusi Semen pada Pembuatan Batako Dalam Kaitannya Dengan Kuat Tekan. IKIP. Jakarta

Murdock, L. J., K. M. Brook, 1999. Bahan Dan Praktek Beton. Erlangga. Jakarta

Pusat Penelitian dan Pengembangan Pemukiman, 1986. Persyaratan Umum Bahan Bangunan di Indonesia. Badan Penelitian Dan Pengembangan P.U. Bandung.

SK SNI S-04-1989-F. 1989. Spesifikasi Air Sebagai Bahan Bangunan. Yayasan LPMB. Bandung

SNI 03-0349-1989, 1989. Bata Beton Untuk Pasangan Dinding. Dewan Standarisasi Nasional. Jakarta.

SNI 03-1750-1990, 1990. Mutu Dan Cara Uji Agregat Beton. Departemen Perindustrian. Jakarta

SNI 03-1754-1990, 1990. Cara Penentuan Kadar Butir Halus Lebih Kecil dari 50 Mikron untuk Agregat Halus Aduk dan Beton. Departemen Perindustrian. Jakarta

SNI 03-1756-1990, 1990. Cara Penentuan Kekerasan Pasir untuk Aduk dan Beton. Dewan Standarisasi Nasional. Jakarta

SNI 03-1970-1990, 1990. Metode Pengujian Berat Jenis dan Penyerapan Air Agregat Halus. Departemen Pekerjaan Umum. Jakarta.

SNI 03-1968-1990, 1990. Metode Pengujian Tentang Analisa Saringan Agregat Halus dan Kasar. Departemen Pekerjaan Umum. Jakarta

SNI 03-2816-1992, Metode Pengujian Kotoran Organik dalam Pasir Untuk Campuran Mortar Atau Beton. Departemen Pekerjaan Umum. Jakarta

Samekto, Wuryati, Candra Rahmadiyanto, 2001. Teknologi Beton. Kanisius. Yogyakarta

Sofiah, Ariana, 2003. Studi Kuat Tekan Bata Beton (Paving Block) Dengan Abu Puing Ubin Keramik Sebagai Bahan Pengganti Sebagian Semen. UNJ. Jakarta.

Sudjana, 1996. Metoda Statistika. Tarsito. Bandung

Supribadi, I Ketut, 1987. IImu Bangunan Gedung. Armico. Bandung

Teguh, Muchamad, 2003. Pengaruh Abu Sekam Padi Sebagai Pengganti Sebagian Semen Pada Beton Terhadap Kuat Tekan Beton. UNJ. Jakarta 